\title{
DEVELOPMENT OF AN ANDROID-BASED HARMONIC OSCILLATION POCKET BOOK FOR SENIOR HIGH SCHOOL STUDENTS
}

\author{
Marsi Bani ${ }^{1}$ (D), Masruddin Masruddin ${ }^{2}$ i \\ ${ }^{1}$ Physics Education Study Program at Nusa Cendana University (Indonesia) \\ ${ }^{2}$ Institut Agama Islam Negeri Palopo (Indonesia) \\ marsibani@staf.undana.ac.id,masruddin_asmid@iainpalopo.ac.id
}

Received July 2020

Accepted October2020

\section{Abstract}

Research has been conducted to develop a physics learning media in the form of an Android-based pocket book. We designed a Harmonic Oscillation Pocket Book and tested its feasibility and effectiveness in improving the cognitive learning outcomes of students. This study used the research and development method adapted from the ADDIE model. The results revealed that this software has been successfully developed and is very feasible to be used as a physics learning medium. This Android-based Harmonic Oscillation Pocket Book was effective in enhancing the students' cognitive learning outcomes, and students showed a tendency to respond positively to the software.

Keywords - Harmonic oscillation, Android, Learning media.

\section{To cite this article:}

Bani, M., \& Masruddin, M. (2021). Development of an android-based harmonic oscillation pocket book for senior high school students. Journal of Technology and Science Education, 11(1), 93-103. https://doi.org/10.3926/jotse.1051

\section{Introduction}

Media is one of the supporting factors for achieving learning goals. The use of appropriate and varied media in the learning process can increase learning motivation and can reduce the passivity of students (Hardianto, 2005). The use of learning media must be applied in all subjects, including physics. Learning media must be packaged in an attractive form to encourage students to spend more time on learning. One learning medium that is often used to overcome the problem of low student interest in bringing books to school is a pocket book.

A pocket book is a small book that can be stored in a pocket and is easy to carry anywhere. Setyono Karmin and Wahyuningsih (2013) argued that pocket books can be interpreted as books that are small, lightweight, easy-to-carry anywhere and can be read at any time. The general definition of a pocket book based on this definition is a small book that contains information and can be stored in a pocket, so that it is easy to carry anywhere. Students can obtain information from a pocket book without spending too much time capturing the essence of the information. A pocket book is considered to make it easier for students to learn, but it has the drawbacks that it is easy to lose and still uses paper. It also tends to be less 
varied, which is not solely the fault of the teacher, but rather due to the lesser degree of optimization of the development of technology.

The development of technology facilitates the performance of human activities in several ways. One example of a technological development is mobile phones. This communication technology is growing rapidly and is very helpful and beneficial for human life. However, not all Indonesians are able to utilize this technology properly. In the world of education, for example, many students use mobile phones during teaching and learning activities. Moreover, the current generation of mobile phones is not only used to send short messages, but also to access the Internet, especially the social media, and to play games. As a result, students prefer to use their cellphones to have fun rather than to learn.

The smartphone is a mobile device that can be used to communicate (send short messages and make telephone calls), and it includes the functions of Personal Digital Assistants (PDAs) and can operate like a mini computer. This smartphone is the result of rapid technological development. According to the Roy Morgan research institute, during the period of March 2012-2013, smartphone ownership in Indonesia doubled from $12 \%$ to $24 \%$ of the total population. The use of smartphones in Indonesia in the second quarter of 2013 reached nearly 15 million units, and the majority of users were teenagers, with an age range of 15-18 years. The Digital Marketing Research Institute Emarketer estimates that by 2018, the number of active smartphone users in Indonesia will be more than 100 million people.

The rapid development of smartphones can be a challenge and an opportunity, especially in the world of education. The challenge is seen from the perspective of the number of cases in which students use mobile phones in class, such as sending short messages, playing games, as well as students who store and watch videos that are inappropriate for teenagers to watch during class. Meanwhile, the opportunity lies in using smartphones in education as innovative, creative and interactive learning media.

Research on the development of Android as a learning medium has previously been conducted. The study by Arumanadi (2014) revealed that Android-based PboP applications have a positive impact on student learning outcomes in physics on the topics of energy, work, and power. Purbasari (2013) found that Android tablets were able to improve material understanding by students, and there is no negative influence on the teaching and learning process in the classroom. However, almost all Android applications developed can only be operated on Android version 4.3 (Jelly Bean) or earlier and only on certain Android platforms. This is in spite of the fact that there are many laterAndroid versions and lots of Android platforms from various brands, namely Android 1.0 (Alpha), Android 1.1 (Beta), Cupcake, Donut, Éclair, Froyo, Gingerbread, Honeycomb, ICS (Ice Cream Sandwich), Jelly Bean, Kit Kat, Lollipop, Marshmallow, and Nougat.

Purwantoro, Rahmawati and Tharmizi (2013) said Android is a software used on mobile devices that includes operating systems, middleware and core applications. According to Satyaputra (2014), Android is an operating system for smartphones and tablets. The operating system can be illustrated as a bridge between the device and its user, so that users can interact with the device and run applications available on the device. Huda (2013) believes Android is a Linux-based operating system that is specific to mobile devices, such as smartphones or tablets. This Android operating system is open source, so many programmers are flocking to create applications or modify this system.

The advantages of Android include: (1) it is a complete platform, which means that developers can take a comprehensive approach when developing for the Android platform; (2) it is an open source platform, so it can be easily developed by users; (3) it is a free platform for developers; and (4) with its popular operating system, Android phones are certainly different from those running the Iphone Operating System (IOS), which is limited to gadgets from Apple. Android has many manufacturers, with their main stay gadgets ranging from those produced by Evercross to Samsung, at affordable prices (Zuliana \& Irwan, 2013)

In contrast to previous research, in this study, the authors have developed an Android-based learning medium based on pocket book software using Adobe Flash CS6, Adobe Air and AIR SDK. This ensures that the resulting Android application can be easily operated and installed on all types of platforms and 
Android versions. Accordingly, this article reports on the development activities of an Android-based pocket book software addressing the topic of harmonic oscillation, in order to determine its feasibility and effectiveness and student response in terms of its practicality.

\section{Methodology}

\subsection{Research Model}

The development of this pocket book software used both research and development methods. This research procedure adapted the ADDIE development model. The ADDIE development model consists of five stages, namely Analysis, Design, Development, Implementation, and Evaluation, however, this study was limited to the implementation stage.

\subsubsection{Analysis}

The pocket book software development began by analyzing the needs of students through a preliminary study at SMA N 2 Kupang and continued with a competency analysis and the determination of the indicators. The data obtained from this preliminary study reveal: (1) students need a learning medium that is packaged in an interesting, easy-to-use and interactive form that can facilitate their independent learning; (2) the basic competencies that will be included in this medium are analyzing the relationship between force and oscillation in everyday life, i.e., the topic of harmonic oscillation.

\subsubsection{Design}

The design stage was a media design stage which included the making of a flowchart, media storyboard, materials, questions and answers, pictures and buttons that will be included in the media.

\subsubsection{Development}

During this stage, all materials were designed in an Android software environment using Adobe Flash CS6 equipment with AIR SDK 23 and Action Script 3.0 as the programming language. The next step was software evaluation by experts. One material expert and two media experts assessed the subject material and media aspects of the application developed.

Evaluation by the material expert was based on the following criteria:

\begin{tabular}{|c|l|c|}
\hline No. & \multicolumn{1}{|c|}{ Indicator } & Item number \\
\hline Material Relevance Aspects (A1) & 1 \\
\hline 1 & Suitability of material in terms of the basic competence & 1 \\
\hline 2 & Suitability of material in terms of the indicator & 1 \\
\hline 3 & Accuracy of the material viewed from a scientific perspective & 1 \\
\hline Material Organization Aspects (A2) & 1 \\
\hline 4 & Clarity of the material delivery & 1 \\
\hline 5 & Systematic material delivery & 1 \\
\hline 6 & Attractiveness of the material & 1 \\
\hline 7 & Comprehensiveness of the material & 1 \\
\hline 8 & Relevance of the material & 1 \\
\hline 9 & Suitability of the level of difficulty and abstractness of the concept \\
\hline 10 & Clarity of examples & 1 \\
\hline Evaluation Aspects (A3) & 1 \\
\hline 11 & Accuracy of the answer key & 1 \\
\hline 12 & Clarity in the formulation of questions & 1 \\
\hline 13 & Accuracy of the concept of the questions & 1 \\
\hline 14 & Variety of questions & 1 \\
\hline 15 & Level of difficulty of the questions & 1 \\
\hline 16 & Clarity in the discussion of the answers & 1 \\
\hline Language Aspects (A4) & \\
\hline 17 & Accuracy of term usage & \\
\hline 18 & Ease of understanding the flow of the material & \\
\hline
\end{tabular}




\begin{tabular}{|c|l|c|}
\hline No. & \multicolumn{1}{|c|}{ Indicator } & Item number \\
\hline \multicolumn{2}{|c|}{ Learning Strategy Effect Aspects (A5) } & 1 \\
\hline 19 & Encouragement of student curiosity & 1 \\
\hline 20 & Medium support for student independence & 1 \\
\hline 21 & Ability of the medium to increase student motivation & \\
\hline
\end{tabular}

Table 1. Indicators of the Media Rating by the Material Expert (Aryantari, 2013)

Meanwhile, evaluation by the media experts was based on the criteria presented in Table 2.

\begin{tabular}{|c|c|c|}
\hline No. & Indicator & Item number \\
\hline \multicolumn{3}{|c|}{ Language Aspects (B1) } \\
\hline 1 & Accuracy of term usage & 1 \\
\hline 2 & Suitability of language, taking into account the students' level of thinking & 1 \\
\hline 3 & Ease of understanding the material & 1 \\
\hline \multicolumn{3}{|c|}{ Learning Strategy Effect Aspects (B2) } \\
\hline 4 & Encouragement of student curiosity & 1 \\
\hline 5 & Medium support for student independence & 1 \\
\hline 6 & Ability of the medium to enhance user knowledge & 1 \\
\hline 7 & Ability of the medium to enhance user comprehension & 1 \\
\hline 8 & Ability of the medium to increase student motivation & 1 \\
\hline \multicolumn{3}{|c|}{ Software Engineering Aspects (B3) } \\
\hline 9 & Creativity and innovation of learning media & 1 \\
\hline 10 & Ease of touch and drag functions & 1 \\
\hline 11 & Ease of operating media & 1 \\
\hline 12 & Ease of re-use & 1 \\
\hline 13 & Ease of maintenance & 1 \\
\hline 14 & Media development opportunity for the development of science and technology & 1 \\
\hline \multicolumn{3}{|c|}{ Visual Display Aspects (B4) } \\
\hline 15 & Suitability of color selection & 1 \\
\hline 16 & Suitability of font type selection & 1 \\
\hline 17 & Suitability of font size selection & 1 \\
\hline 18 & Accuracy of button placement & 1 \\
\hline 19 & Suitability of display image & 1 \\
\hline 20 & Display proportions & 1 \\
\hline 21 & Attractiveness of the design & 1 \\
\hline
\end{tabular}

Table 2. Indicators of the Media Rating by the Media Experts (Aryantari, 2013)

The expert opinions were collected by means of a questionnaire using a Likert scale. The responses were then converted into qualitative data by comparing the percentage of scores obtained with the feasibility reference, as shown in Table 3.

\begin{tabular}{|c|c|}
\hline \% Score & Interpretation \\
\hline $80-100 \%$ & Very feasible \\
\hline $60-79 \%$ & Feasible \\
\hline $50-59 \%$ & Inadequate \\
\hline$<49 \%$ & Not feasible \\
\hline
\end{tabular}

Table 3. Media Feasibility Reference (Arikunto, 2010) 


\subsubsection{Implementation}

In the implementation stage, the Harmonic Oscillation Pocket Book was used by students in grade $\mathrm{X}$ at SMA Negeri 2 Kupang. Students were allowed to install and use the software on their mobile phones. The purpose of this stage was to evaluate the effectiveness of products developed in improving the cognitive learning outcomes of students. Therefore, in this stage the quasi-experimental method used involved a matching-only pretest-posttest control group design (Fraenkel, Wallen \& Hyun, 2012), where the experimental class (consisting of 26 students) learned using an Android-based pocket book, while the control class (consisting of 27 students) learned using traditional textbooks.

Student learning outcomes were assessed by means of a Harmonic Vibration Concept Comprehension Test developed by the researcher, the validity and reliability of which had been previously tested.

The product developed is said to be effective in improving cognitive learning outcomes if the mean $\mathrm{N}$-gain score of cognitive learning outcomes of students who learned using this product is significantly higher than the mean $\mathrm{N}$-gain score of cognitive learning outcomes of students who learned using textbooks. The N-gain calculation refers to the equation reported by Hake (Meltzer, 2002), while the Mann-Whitney test was used for the mean difference, calculated using the SPSS program, with a significance level of $5 \%$.

At the end of the learning activity, students in the experimental group were asked for their response to the product, developed by completing the questionnaire given. The student response indicators are presented in Table 4.

\begin{tabular}{|c|l|c|}
\hline No. & Indicator & Item number \\
\hline 1 & Attractive delivery of material (C1) & 1 \\
\hline 2 & Clarity of examples/questions (C2) & 1 \\
\hline 3 & Ability to encourage student curiosity (C3) & 1 \\
\hline 4 & Ability of the medium to improve student understanding (C4) & 1 \\
\hline 5 & Capabilities of the medium to increase student motivation (C5) & 1 \\
\hline
\end{tabular}

Table 4. Indicator of Student Responses on the Questionnaire

\section{Results and Discussion}

\subsection{Results}

\subsubsection{Description of the Android-based Harmonic Oscillation Pocket Book Product}

The final result of these development stages was an Android-based software entitled Buku Saku Getaran Harmonis (Harmonic Oscillation Pocket Book), with an .apk file extension. There are 5 menu buttons on the main menu screen (Figure 1), namely: (1) KI/KD (Competence), (2) Materi (Material), (3) Kuis (Quiz), (4) Pengembang (Developer) and (5) Power button.

TheKI/KD button displays a page consisting of the core and basic competence. This competence is in line with Kurikulum 2013 Revisi (the curriculum used at the school), which is analyzing the relationship between force and oscillation in everyday life. The Materi button displays the material screen that presents the learning material (Figure 2). There is a scroll bar that can be used to read further information that is loaded. This section also provides examples, questions and discussions that will facilitate the user's understanding of the materials.- On the Kuis screen, the user will be asked to answer questions. Each question has four options, from which the user is allowed to choose one. A score box is provided to show the user's score (Figure 3). Every action receives feedback from the software. If the answer is correct, the software will display the correct answer page (Figure 4a), whereas if the answer is false, the false page will appear (Figure 4b). At the end of this section, the software shows "There are no more questions" and a blue reload button restarts the quiz from the beginning (Figure 4c). The developer button displays the developer page, which shows information about the software developer. The power button exits the application. 


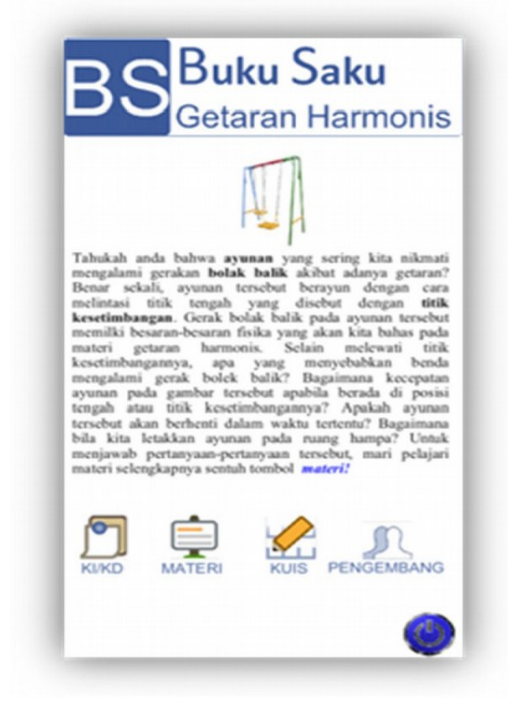

Figure 1. Main Menu Page
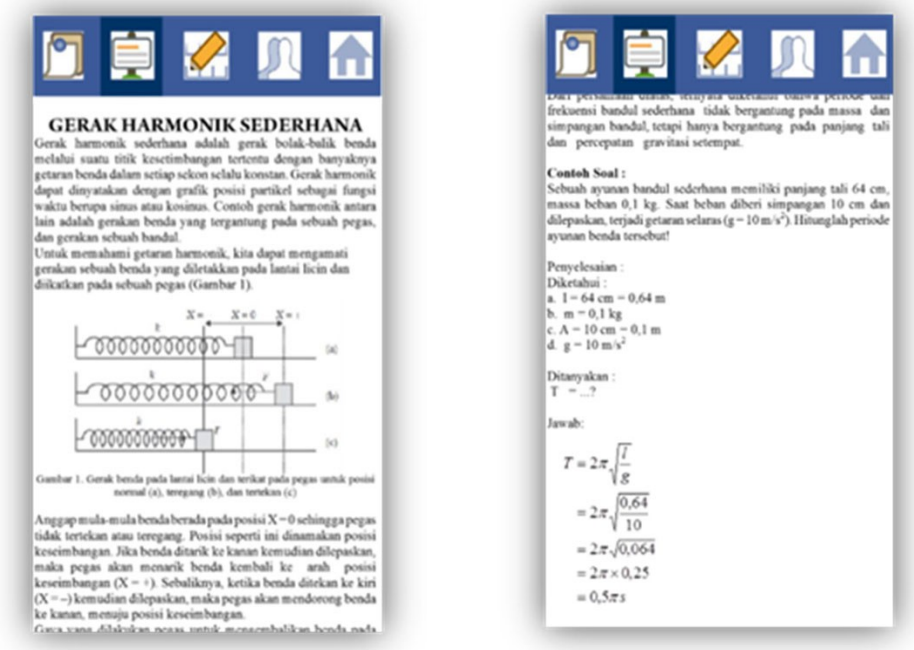

Figure 2. Material Page

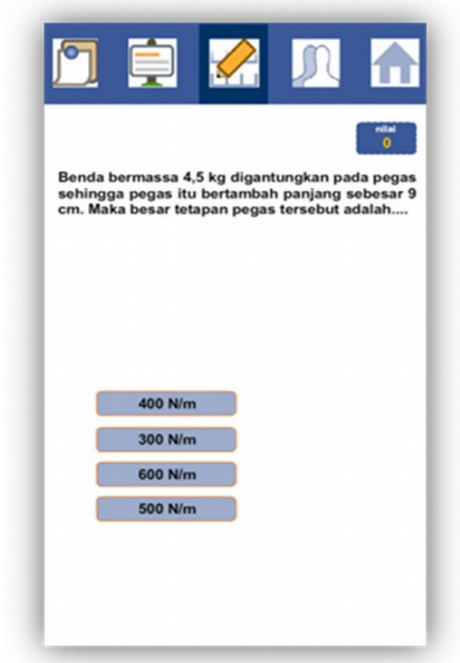

Figure 3. Quiz Page 


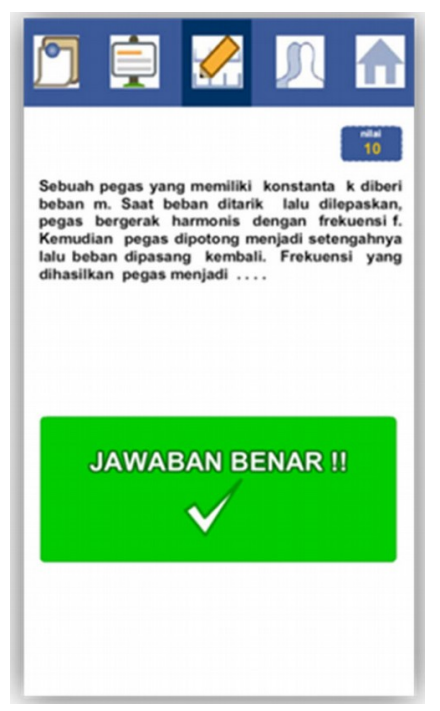

(a)

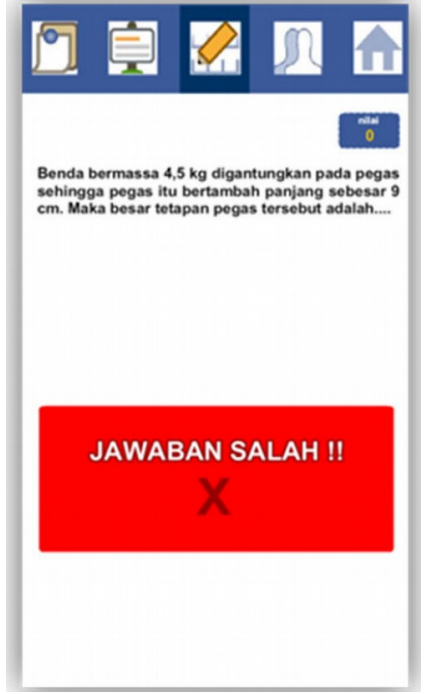

(b)

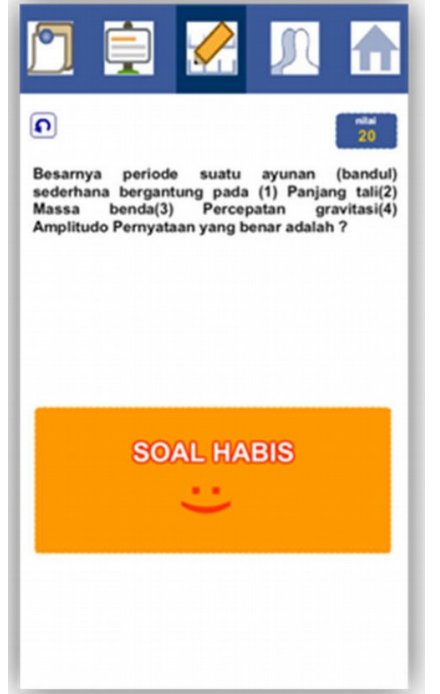

(c)

Figure 4. Feedback on User Answers

\subsubsection{Feasibility Test Results for the Android-based Harmonic Oscillation Pocket Book}

The result of the assessment by the material and media experts is presented sequentially in Figure 5 and Figure 6.

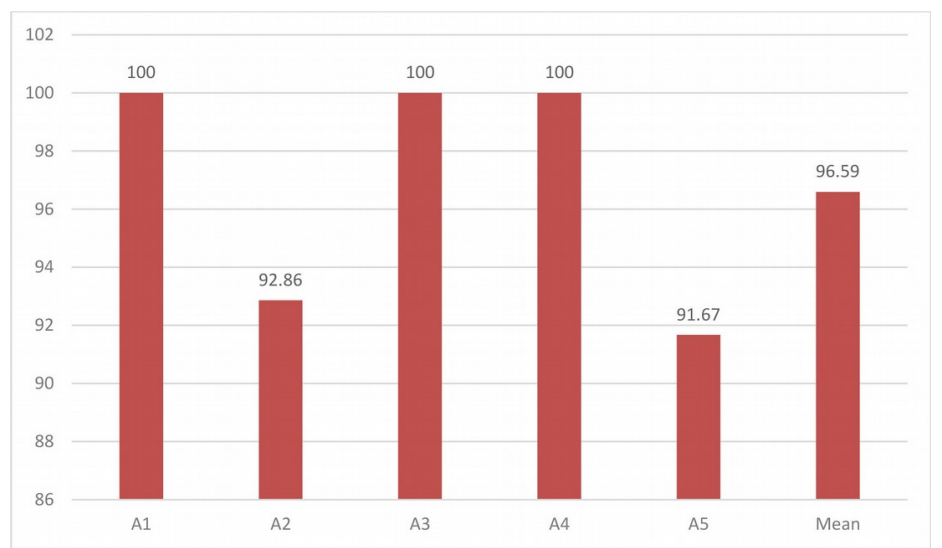

Figure 5. Bar Chart of the Material Expert Assessment Result Percentages

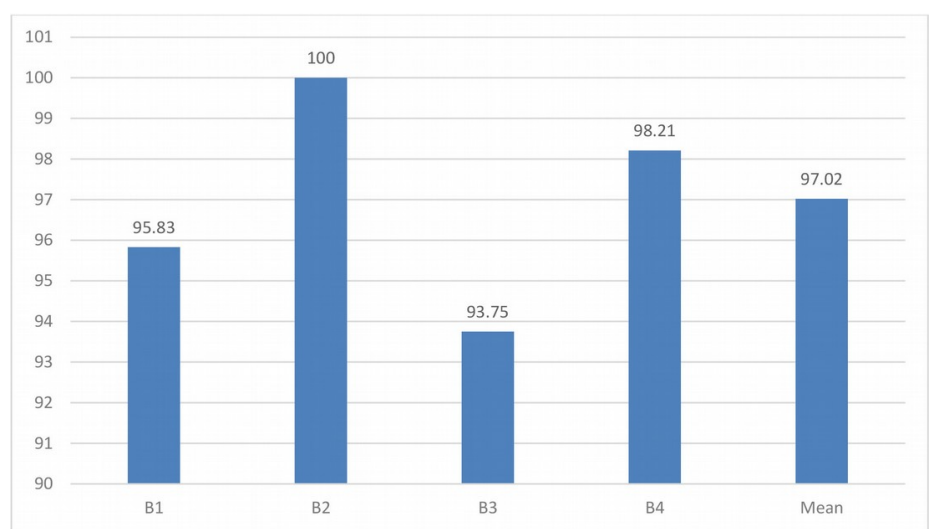

Figure 6. Bar Chart of the Media Expert Assessment Result Percentages 
Data from the feasibility assessment by the material experts resulted in a percentage of $96.59 \%$ (very feasible), and thus this medium is feasible as a medium for learning physics, according to the material experts. This is so because in this Android-based pocket book the clarity of the learning objectives, systematic presentation of the material, clarity of the description of the material, clarity of the learning instructions, examples, training, strengthening, feedback and motivation are sufficient. In addition, in terms of content, the presence of images and animation to clarify the material and the clarity of the language used allow students to easily understand its contents, so that this medium can also be used independently in guiding students throughout their learning activity. This is in line with the opinion expressed by Daryanto (2013) that the characteristics of good media are that they are independent, in the sense of providing ease and completeness of content in such a way that users can use them without the guidance of others.

Assessment results from the media experts on the feasibility of this Android-based Harmonic Oscillation Pocket Book reached a percentage of $97.02 \%$ (very feasible), and thus based on the assessment of media experts, this Android-based HarmonicOscillationPocket Book can be said to be very feasible as a medium for learning physics. This is because this medium is easy to use, and is easy for the users to freely select the menu that is displayed. In addition, the appearance of the medium is quite good in terms of the selection of fonts, font size, placement of images and animation, layout and color. This is consistent with the opinion of Thorn regarding good multimedia assessment criteria, namely: (1) ease of navigation, where interactive multimedia must be designed as simple as possible, so that students can learn without having to have complex knowledge of the media; (2) artistic and aesthetic criteria, according to which, in order to promote an interest in learning, the program must have an attractive appearance and good aesthetic qualities. Furthermore, this Android-based HarmonicOscillationPocket Book is designed to be interactive, including the handling of student responses, such as giving feedback when students answer correctly or incorrectly. This is in line with the opinion of Daryanto (2013), who stated that good media are interactive, in the sense of having the ability to accommodate user responses.

\subsubsection{The Impact of the Android-based Harmonic Oscillation Pocket Book on Student Comprehension of the Concept of Harmonic Oscillation}

The cognitive learning outcomes of the students were determined by means of a pretest and posttest. A comparison of the results of the cognitive learning outcomes of the students from the two groups can be seen in Table 5. Furthermore, the results of the mean difference test of the $\mathrm{N}$-gain values in the two classes are shown in Table 6.

\begin{tabular}{|c|l|c|c|c|c|}
\hline \multirow{2}{*}{ No. } & \multirow{2}{*}{ Variable } & \multicolumn{2}{c|}{ Android-based pocket book } & \multicolumn{2}{c|}{ Textbook } \\
\cline { 3 - 6 } & & Pretest & Posttest & Pretest & Posttest \\
\hline 1. & Maximum score & 58.62 & 86.21 & 48.28 & 86.21 \\
\hline 2. & Minimum score & 13.79 & 72.41 & 13.79 & 62.07 \\
\hline 3. & Mean score & 30.90 & 80.00 & 29.77 & 74.71 \\
\hline 4. & Std. Dev. & 11.84 & 5.63 & 8.57 & 6.36 \\
\hline 5. & Mean of the N-gain & \multicolumn{2}{|c|}{0.71} & \multicolumn{2}{c|}{0.64} \\
\hline
\end{tabular}

Table 5. Comparison of Cognitive Learning Outcomes of Students

\subsubsection{Independent Samples Test}

Based on the data analysis, it was found that both groups of students experienced an increase in cognitive learning outcomes after the treatment. This is because students in both groups learn using media with a similar presentation construct. The material presented in the Android-based pocket book and textbook used in both groups was designed based on the principles of educational multimedia development proposed by Mayer (2009) to boost the students' learning process. The medium presents images and animations accompanying the text on a single page, based on the multimedia principle that students can 
learn better with both words and images as opposed to only words; the principle of space proximity, which states that students can learn better if related words and images are presented close together; and the principle of time proximity, which says that students can learn better if words and pictures which are related are presented simultaneously, rather than successively (Mayer, 2009).

\begin{tabular}{|c|c|c|c|c|c|c|c|c|c|c|}
\hline & \multicolumn{2}{|c|}{$\begin{array}{l}\text { Levene's Test } \\
\text { for Equality } \\
\text { of Variances }\end{array}$} & \multicolumn{7}{|c|}{ T-test for Equality of Means } \\
\hline & & \multirow[b]{2}{*}{$\mathbf{F}$} & \multirow[b]{2}{*}{ Sig. } & \multirow[b]{2}{*}{$\mathbf{T}$} & \multirow[b]{2}{*}{ Df } & \multirow{2}{*}{$\underset{\text { (2-tailed) }}{\text { Sig. }}$} & \multirow{2}{*}{$\begin{array}{c}\text { Mean } \\
\text { Difference }\end{array}$} & \multirow{2}{*}{$\begin{array}{l}\text { Std. Error } \\
\text { Difference }\end{array}$} & \multicolumn{2}{|c|}{$\begin{array}{l}95 \% \text { Confidence } \\
\text { Interval of the } \\
\text { Difference }\end{array}$} \\
\hline & & & & & & & & & \begin{tabular}{|l|} 
Lower \\
\end{tabular} & Upper \\
\hline \multirow{2}{*}{$\begin{array}{l}\text { N-gain } \\
\text { Hasil } \\
\text { Belajar } \\
\text { Kognitif }\end{array}$} & \begin{tabular}{|l} 
Equal \\
variances \\
assumed
\end{tabular} & 0.330 & 0.568 & 4.125 & 53 & 0.000 & 0.06853 & 0.01661 & 0.03521 & 0.10185 \\
\hline & \begin{tabular}{|l|} 
Equal \\
variances not \\
assumed
\end{tabular} & & & 4.113 & 50.604 & 0.000 & 0.06853 & 0.01666 & 0.03508 & 0.10199 \\
\hline
\end{tabular}

Table 6. T-test Results of the $\mathrm{N}$-gain scores for the Student Cognitive Learning Outcomes

However, the increase in the cognitive learning outcomes of students who learn using the Android-based Harmonic Oscillation Pocket Book was higher than for those who learned using textbooks. This result is strengthened by the result of the mean difference test, which statistically showed that the difference was significant $(\mathrm{t}(53)=4.125, \mathrm{p}<0.05)$. This is because the Android-based pocket book has among its advantages that it can display dynamic images, as compared to books, which are only capable of displaying static images.

Simple harmonic oscillation is a special type of periodic motion or oscillation motion in which the restoring force is directly proportional to the displacement and acts in the direction opposite to that of displacement. The motion is periodic, repeating itself in a sinusoidal fashion, with a constant amplitude A. In addition to its amplitude, the motion of a simple harmonic oscillator is characterized by its period $\mathrm{T}$, the time for a single oscillation, and its frequency $f=1 / T$, the number of cycles per unit of time. The position at a given time $\mathrm{t}$ also depends on the phase $\varphi$, which determines the starting point on the sine wave. The period and frequency are determined by the size of the mass $m$ and the force constant $k$, while the amplitude and phase are determined by the starting position and velocity. Therefore, it will be easier to understand if the students can observe the changes in position and their relationship with sine charts simultaneously. For example, in presenting the motion of a spring, students can observe the movement of the springs macroscopically and microscopically when conducting vibrations. They can also simultaneously watch the formation of sinusoidal charts at the same time, which cannot be shown by static images in the textbook. Students who are still in the concrete operational and formal operational phases will be helped by the presence of images and animations presented in this medium, because based on the characteristics of the material, there are parts that cannot be observed directly. These aspects will become more concrete if visualized, helping the students to form representations mentally.

In addition, the presentation of material descriptions avoided images or animations that were not related to the material, even if the image or animation looked interesting. This is based on the principle of coherence, which states that student learning will be disrupted if interesting, but irrelevant words or images are added to multimedia presentations (Mayer, 2009).

In the learning process, students tend to be more interested in using this Android-based pocket book application as compared to textbooks. The result of the student response toward this medium for each indicator (see Table 4) can be seen in Figure 7. 


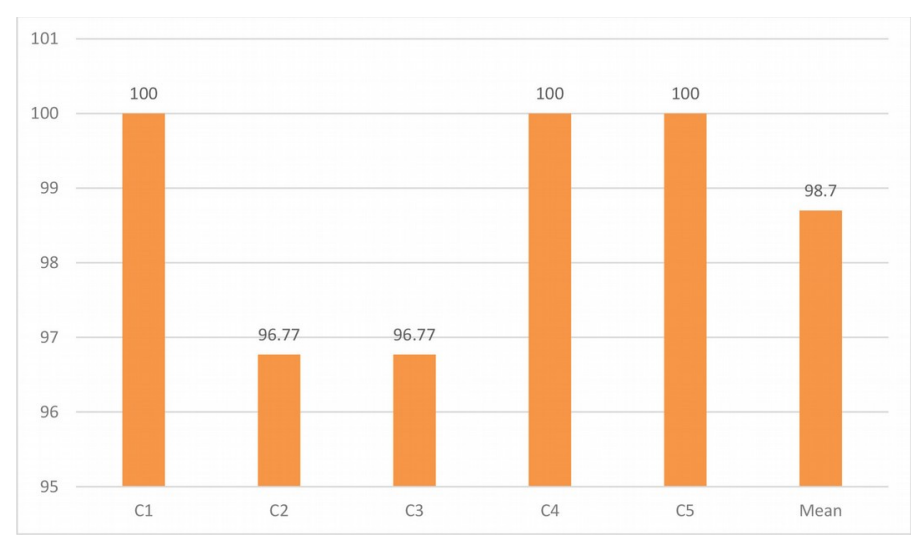

Figure 7. Bar Chart of Student Response Percentages

Since it was developed according to the needs of students, it is easy to use by students. This has an impact on the response of students, which was $98.7 \%$ positive. Students feel interested in learning using this application, because it is considered easier to carry around than textbooks. In addition, the existence of this Android-based learning application makes them aware that their smartphones can be used for more useful things.

\section{Conclusions}

From the results of the software development, it can be concluded that this Android-based Harmonious Oscillation Pocket Book has been successfully developed throughout all four stages, namely analysis, design, development and implementation. The resulting Harmonic Oscillation Pocket Book is of very good quality and is very worthy of being used as a medium for learning physics. The students' response to this medium is very positive, thus demonstrating that the medium is considered practical to use. The results of this study support the further development of Android-based learning media.

\section{Declaration of Conflicting Interests}

The authors declared no potential conflicts of interest with respect to the research, authorship, and/or publication of this article.

\section{Funding}

The authors received no financial support for the research, authorship, and/or publication of this article.

\section{References}

Arikunto, S.(2010). Prosedur Penelitian Suatu Pendekatan Praktik. Jakarta: Rineka Cipta.

Arumanadi, L. (2014). Pengembangan Aplikasi Pocket Book of Physics (PBOP) Sebagai Media Pembelajaran Fisika SMA Kelas XI untuk Platform Android. Thesis. Faculty of Mathematics and Science. Yogyakarta State Univerisity.

Aryantari, W.R. (2013). Pengembangan Mobile Edukasi Berbasis Android Sebagai Media Pembelajaran Akuntansi untuk Siswa Kelas XI IPS SMA. Thesis. Faculty of Economy, Yogyakarta State University.

Daryanto. (2013). Media pembelajaran: Perancangan sangat penting dalam mencapai tujuan pembelajaran. Yogyakarta: Gava Media.

Fraenkel, J.R., Wallen, N., \& Hyun, H. (2012). How to Design and Evaluate Research in Education (8th ed.). New York: McGraw-Hill.

Hardianto, D. (2005). Media Pendidikan sebagai Sarana Pembelajaran yang Efektif. Majalah Ilmiah Pembelajaran,1(1), 95-104. 
Huda, A.A. (2013). Live Coding! 9 Aplikasi Buatan Sendiri. Yogyakarta: Andi.

Mayer, R.E. (2009). Multimedia Learning: Prinsip-prnsip dan Aplikasi (Teguh Wahyu Utomo, trans).

Yogyakarta: Pustaka Pelajar. https://doi.org/10.1017/CBO9780511811678

Meltzer. (2002). The relationshipbetweenmathematicspreparationandconceptuallearninggains in physics: A possible "hiddenvariable" in diagnosticpretestscores. American Association of Physics Teachers, 70(12), 1259-1268. https://doi.org/10.1119/1.1514215

Materi Dimensi Tiga untuk Siswa SMA kelas X. Jurnal Pendidikan Matematika, 1(2), 3-11.

Purwantoro, S., Rahmawati, H., \& Tharmizi, A. (2013). Mobile Searching Objek Wisata Pekanbaru Menggunakan Location Base Service (LBS) Berbasis Android. Jurnal Politeknik Caltex Riau,1(1), 177-185.

Satyaputra, A. (2014). Beginning Android Programming with ADT Budle. Jakarta: Elex Media Komputindo.

Setyono, Y.A., Karmin, S., \& Wahyuningsih, D. (2013). Pengembangan Media Pembelajaran Fisika berupa Bulletin dalam bentuk Buku Saku untuk Pembelajaran Fisika Kelas VIII Materi Gaya ditinjau dari Minat Baca Siswa. Jurnal Materi dan Pembelajaran Fisika, 1(1) 118-126.

Zuliana, \& Padli, I. (2013). Aplikasi Pusat Panggilan Tindakan Kriminal di Kota Medan Berbasis Android. Jurnal LAIN Sumatera Utara Medan,1(2), 2-4.

Published by OmniaScience (www.omniascience.com)

Journal of Technology and Science Education, 2021 (www.jotse.org)

\section{(c) (1) (8)}

Article's contents are provided on an Attribution-Non Commercial 4.0 Creative commons International License. Readers are allowed to copy, distribute and communicate article's contents, provided the author's and JOTSE journal's names are included. It must not be used for commercial purposes. To see the complete licence contents, please visit https://creativecommons.org/licenses/by-nc/4.0/. 